Original Research Article

\title{
Is there a way to rate insecticides that is less detrimental to human and environmental health?
}

\author{
Cristian Bolzonella ${ }^{a}$, Marco Lucchetta ${ }^{a}$, Gianni Teo a , Vasco Boatto ${ }^{\text {b }}$, \\ Augusto Zanella ${ }^{\mathrm{b}, *}$ \\ ${ }^{\text {a }}$ Cirve - Interdepartmental Center of Oenology and Viticulture - University of Padua, via XXVIII Aprile 14, 31015, Conegliano, TV, Italy \\ ${ }^{\mathrm{b}}$ TESAF - Department of Land, Environment, Agriculture and Forestry - University of Padua, Viale dell'Università 16, 35020, Legnaro, PD, \\ Italy
}

\section{A R T I C L E I N F O}

\section{Article history:}

Received 9 April 2019

Received in revised form 30 June 2019

Accepted 30 June 2019

\section{Keywords:}

Insecticides

Biodiversity decline

Sustainable viticulture

Human health

Vine cultivation

\begin{abstract}
A B S T R A C T
Plant protection is essential for providing high-quality food in adequate quantities. However, the use of insecticides often induces adverse effects on environment and human health. The Agency for the Environmental Protection of Tuscany (Italy) arranges pesticide ingredients in five classes basing on their impact on human health. We classified the pesticide treatments carried out by 48 winegrowers of the Veneto Region (Italy) in relation to the active ingredients contained into the used pesticides over a three-year period (2015 -2017). It was found that the cost of insecticides and their class of impact were related, and that the cost's pressure led farmers to favor insecticides with active ingredients having a high negative impact on human health. The same active ingredients are used worldwide. We propose to implement taxation measures and subsidies to deter the use of the most harmful insecticides.

(C) 2019 The Authors. Published by Elsevier B.V. This is an open access article under the CC BY-NC-ND license (http://creativecommons.org/licenses/by-nc-nd/4.0/).
\end{abstract}

\section{Introduction}

The use of pesticides helped to prevent the death of millions of people by reducing pest populations that carry or transmit diseases, such as malaria, transmitted by infected mosquitoes, the bubonic plague, carried by rat fleas, and typhus, transmitted by both fleas and body lice (Hart and Pimentel, 2002; Pimentel, 2005). Over the years, the widespread use of pesticides had several benefits and also caused many problems for both human health and the environment (Mascarelli, 2013). In agriculture, plant protection is essential for providing high-quality food in adequate quantities. Conventional pesticides (herbicides, fungicides, insecticides, nematicides and rodenticides) are chemically-based and have a specific action on target harmful organisms. They are used everywhere, from commercial agriculture to institutions, and even for domestic issues. Active chemical ingredients are combined with water, solvents, and emulsifiers, in addition to other chemical and nochemical ingredients to repel, kill and control pests in the garden or the environment (Pimentel, 2005).

Many insecticides, however, have been considered inefficient; they often do not target the pest they are intended to control while adversely affecting other species and having negative impacts on the environment and human health (Horrigan et al., 2002). Therefore, the widespread use of insecticides has caused socio-economic and environmental externalities (Matyjaszczyk et al., 2019; Moeder et al., 2012; Zilberman and Millock, 1997). Conventional insecticides are among the most

\footnotetext{
* Corresponding author.

E-mail address: augusto.zanella@unipd.it (A. Zanella).
} 
popular chemicals control agents because they are readily available, rapid-acting and highly reliable. The effectiveness of an insecticide usually depends on when and where a pest encounters it. Most insecticides are absorbed directly through an insect's exoskeleton, and these compounds are immediately active upon contact. Other insecticides act as fumigants and enter the insect's body through its tracheal system. Other compounds, known as stomach poisons, must be ingested to be effective (Sarwar, 2015). Pesticides have been found to impact water quality through percolation and runoff (HerreroHernández et al., 2017; Pimentel, 2005). Fungicides and insecticides are applied at practically all development phases of plants (also during storage), and their residues can be persistent in crop seeds (Remlein-Starosta et al., 2015). The overuse of chemical insecticides led to the fast-growing development of resistance in targeted insect pests and had adverse effects on non-targeted organisms (Benelli, 2018). Earthworms are especially negatively impacted (De Gerónimo et al., 2018; Spina et al., 2018). In this way, pesticides affect other animals along the food chain, such as birds and fish, ultimately resulting in wildlife losses and biodiversity reduction (Barca et al., 2016; Datta et al., 2016; Hallmann et al., 2014; Gross, 2015; Hallmann et al., 2014; Lehikoinen et al., 2018; Pimentel, 2005; Stanton et al., 2018).

Since the late 1970s, a wealth of scientific research from different disciplines shed light on the off-farm human health and the environmental risks of pesticide use (Vernier et al., 2017), concluding that an indiscriminate use of chemical inputs in the agricultural production system cannot be environmentally or socially sustainable in the long term (Travisi et al., 2004). Such improper use of pesticides reduces soil biodiversity, destabilizes soil structure and increases the greenhouse effect (Bertrand et al., 2015; Datta et al., 2016; Khalil and Osborne, 2018; Marín-Benito et al., 2017; Meersmans et al., 2009; Pelosi et al., 2014; Prashar and Shah, 2013; Zanella et al., 2018). At the same time, an indiscriminate use of insecticides induces adverse effects on human health (Ansari et al., 2014; Nicolopoulou-Stamati et al., 2016), with severe risks even to fetal development (Gilden et al., 2010). Finally, insecticides are an essential cause of the troublesome decline of insectivorous birds in the world (Hallmann et al., 2014).

In Western countries the demand for safe foods products is increasing, given a higher awareness of the general public on the importance of both protecting the environment and living in a more sustainable and healthy way (Bertrand et al., 2015; Datta et al., 2016; Lidskog and Elander, 2012; Pergola et al., 2018; Prashar and Shah, 2016; Spina et al., 2018). In order to meet public demand, agriculture must improve sustainability and guarantee the protection of natural resources (especially soil and water), as well as prevent possible harms to human health and other living organisms. The consequences on human health are also known and depend on the assimilation of the active pesticide ingredients or their combined action (SCHEER, 2018). Various European countries have introduced National Action Plans on pesticide use (Directive, 2009/128/EC) to regulate the use of insecticides and favor their sustainable use in agriculture. A reduction of insecticide may be obtained through various means, such as economic strategies (e.g., pesticide taxes) and legislative regulators (Skevas et al., 2012).

The FAOSTAT database (FAO, 2019) reports a pesticide consumption of 6,6 kg active ingredients per hectare per year in Italy, placing Italy among the countries with a high use of chemicals for controlling pests. Nonetheless, sustainable agriculture is a leading and expanding sector with a top ranking of investors. Particularly, viticulture represents a crucial branch of agriculture with a significant economic value in several Italian regions and grapevine is a popular crop in the Italian peninsula (https://italianwinecentral.com/resources/facts-figures/). In many Italian regions, winegrowers have been dependent on insecticide applications to guarantee a high-quality, high-yield grape production.

Even though pesticide residues in Italian agricultural top soils are lower than in other European countries (Silva et al., 2019), which means pesticides are used in ways that reduce soil damage, the investigated area has the highest percentage of agricultural land dedicated to viticulture and the highest use of pesticides per hectare in Italy. Organic farming is increasing and covers about $6 \%$ of the vineyard surface nowadays. The most harmful insects affecting grape yields in north-eastern Italy are Lobesia botrana, Planococcus Ficus, and Scaphoideus titanus, known as the European grapevine moth, the vine mealybug, and the American grapevine leafhopper, respectively (Lucchi, 2014). These insects have an indirect effect on the grapevine and grape quality. For example, the Scaphoideus titanus transmits flavecence doreé (Bianco et al., 2001), and grape berry moth larvae transmit Botrytis cinerea (Fermaud M., 1992). In this scenario, we decided to study and analyze the use of insecticides by wine grape growers in Italy and the relationship between the cost of the products used and their potential impacts on human health.

\section{Material and methods}

\subsection{Treatments and data collection from wine grape growers}

Data from 48 wine grape growers in the Veneto Region located in north-eastern Italy were collected. Since 2012, a legislative decree has required all growers to keep a register for recording all types of anti-parasite treatments applied to their crops. In this register, growers must report the date of all pesticide treatments, the commercial name of the product used and its principal active ingredients, the quantity of product used, the treated area and its size, the reasons that made the treatment necessary, and the name of the worker that carried out the treatment. We used these actual registers to quantify the number of pesticide treatments carried out and the commercial products used from 2015 to 2017.

\subsection{Cost of insecticides, main active ingredients and potential impact class}

The cost of the insecticides comes from 13 different suppliers by means of a requested price quote. The survey was addressed to growers belonging to small (less than 1 ha), medium (between 3 and 10 ha) and large-scale (more than 10 ha) 
vinefarms. Insecticides contained one or more active ingredients. We attributed a potential impact class to each treatment referring to the active ingredient with the highest percentage.

\subsection{Determination of the potential impact class on human health (PICHE)}

The potential impact of insecticides on human health (PICHE) follows the indications of the Regional Agency for the Environmental Protection of the Tuscan Region (Franchi and Arpat Direzione Tecnica, 2017). The PICHE considers the impact of an acceptable daily dose of active ingredient on the "body targets", such as the endocrine and reproductive systems, mutagenic and carcinogenic effects, and organs damage. A score from 1 (low effect) to 3 (high effect) is assigned to each body target as shown in Table 1. The PICHE is obtained by summing the Impact Values of each body target effect. Total Impact Values (TIV) are assigned to PICHE as follows: TIV from 6 to $7=$ PICHE 1; TIV 8-9=PICHE 2; TIV 10-14=PICHE 3; TIV 15-16 = PICHE 4; TIV 17-18, or Impact Value equal 3 even for a single body target effect $=$ PICHE 5 . In the Veneto Region, farmers use also PICHE 1 products, such as fatty acids, unsaturated potassium salts, azadirachtin A, Bacillus thuringiensis and acibenzolar-S-methyl.

Although we focused on human health PICs, the Regional Agency for the Environmental Protection of the Tuscan Region offers tables with PICs for the environment and water. The environmental PIC is an indication of the active ingredients' toxicity for mammals, birds, fish, aquatic invertebrates and earthworms. The water PIC indicates the active ingredients' leachability, water solubility, and soil-, water-, sediment-persistence.

\subsection{Statistical analysis}

The data were set in a table with two columns (PICHE $=$ Potential impact class on human health of the insecticide treatments; COST = the treatments' cost) and 433 lines (number of treatments carried out in 2015, 2016 and 2017, in 48 farms located in the Veneto Region). In a first phase we verified the existence of the correlation between COST and PICHE; later, through a Kruskal-Wallis non-parametric test we associated COST populations and PICHE; finally we grouped data into two opposed categories of COST populations and PICHE, in order to simplify a possible economic/legislative regulation intervention.

\section{Results: insecticides and impacts on human health are related}

A linear model furnished the following relationship between the variables COST $\left(€ \mathrm{ha}^{-1}\right)$ and PICHE: COST $=76.16-8.75 \mathrm{x}$ PICHE; $\left(p<2 \times 10^{-6}\right.$ for $t$ values of both intercept and slope) (Fig. 1). A correlation between COST and PICHE was established $\left(r=-0.778 ; r^{2}=0.61\right.$, corresponding to nearly $61 \%$ of explained variance). A Kruskal-Wallis test determined that the differences between the variance of the dependent variable COST in the four levels $\left(1,2,3\right.$ and 5) are highly significative $\left(p<2 \times 10^{-6}\right)$ (Fig. 1). There were no treatments attributable to PICHE 4 and those of PICHE 2 and 3 were 10 times less numerous than those of PICHE 2 and 5. A Tukey HSD assessed that the COSTs of PICHE 5 treatments were different from the COSTs of all other PICHE treatments $\left(p<2 \times 10^{-6}\right)$, but that the COSTs of treatments assigned to PICHE 1, 2 and 3 are not different from each other (Fig. 1). Consequently, the focus shifts to the difference between the COST of treatments of PICHE 5 against the ones of all other treatments grouped into one category called PICHE 2 (Fig. 2). The difference between the two categories of treatments' COST was noticeable and allows us to suggest a political intervention that might solve a worrying situation.

Table 1

Quality profile for the active ingredients on human health. Slightly simplified from Franchi and Arpat Direzione Tecnica (2017). Referring to Regulation (EC) No 1272/2008 on classification, labelling and packaging of substances and mixtures (the CLP Regulation).

\begin{tabular}{|c|c|c|c|c|c|}
\hline \multirow[t]{3}{*}{ Target effects } & \multirow[t]{3}{*}{ Indicators } & \multicolumn{3}{|l|}{ Impact Values } & \multirow[t]{3}{*}{ Data source } \\
\hline & & 1 & 2 & 3 & \\
\hline & & low & moderate & high & \\
\hline $\begin{array}{l}\text { Acceptable } \\
\text { daily dose }\end{array}$ & mg kg ${ }^{-1}$ body weight & $>0,1$ & $0,01-0,1$ & $\leq 0,01$ & $\begin{array}{l}\text { http://sitem.herts.ac.uk/aeru/ppdb/http:// } \\
\text { ec.europa.eu/food/plant/pesticides/eu- } \\
\text { pesticides-database }\end{array}$ \\
\hline $\begin{array}{c}\text { Endocrine } \\
\text { system }\end{array}$ & Endocrine disruption. Cat. 3a & possible & possible & yes & $\begin{array}{l}\text { http://ec.europa.eu/environment/chemicals/ } \\
\text { endocrine }\end{array}$ \\
\hline $\begin{array}{l}\text { Reproductive } \\
\text { system }\end{array}$ & $\begin{array}{l}\text { Effects on the reproduction } \\
\text { system. CLP without hazard } \\
\text { identification }\end{array}$ & possible & possible & yes & $\begin{array}{l}\text { https://echa.europa.eu/it/information-on- } \\
\text { chemicals }\end{array}$ \\
\hline $\begin{array}{l}\text { Mutagenic } \\
\text { effects }\end{array}$ & $\begin{array}{l}\text { Mutagenesis. CLP without } \\
\text { hazard identification }\end{array}$ & possible & possible & yes & $\begin{array}{l}\text { https://echa.europa.eu/it/information-on- } \\
\text { chemicals }\end{array}$ \\
\hline $\begin{array}{l}\text { Carcinogenic } \\
\text { effects }\end{array}$ & Carcinogenesis. IARC 3 & possible & possible & yes & https://www.iarc.fr \\
\hline Organs & $\begin{array}{l}\text { Organ damage. CLP without } \\
\text { hazard identification }\end{array}$ & $\begin{array}{l}\text { Hazard } \\
\text { Statement } \\
\text { Codes: H371/ } \\
373\end{array}$ & $\begin{array}{l}\text { Hazard } \\
\text { Statement } \\
\text { Codes: H371/ } \\
373\end{array}$ & $\begin{array}{l}\text { Hazard } \\
\text { Statement } \\
\text { Codes: H370/ } \\
372\end{array}$ & $\begin{array}{l}\text { https://echa.europa.eu/it/information-on- } \\
\text { chemicals }\end{array}$ \\
\hline
\end{tabular}




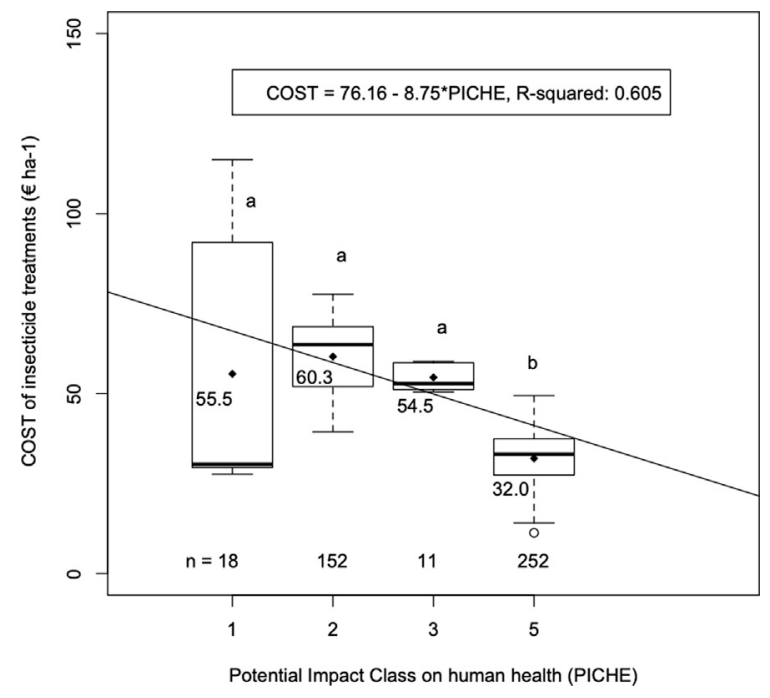

Fig. 1. Boxplot of dependent variable COST of insecticide treatments against factor PICHE (1, 2, 3 and 5 levels), with median (thick line in the box), first (down) and third (up) quartiles-sides of the box, and 95\% confidence interval of median (whiskers). We added the COST-PICHE regression line with the squared $r$ indicating the amount of variance explained by the model (about 60\%), the mean (rhomboid point in the boxes), the two classes (a, b) with the Tukey test distinguished with an almost null probability $\left(20^{-6}\right)$ to belong to the same population, and the number of investigated treatments in each class.

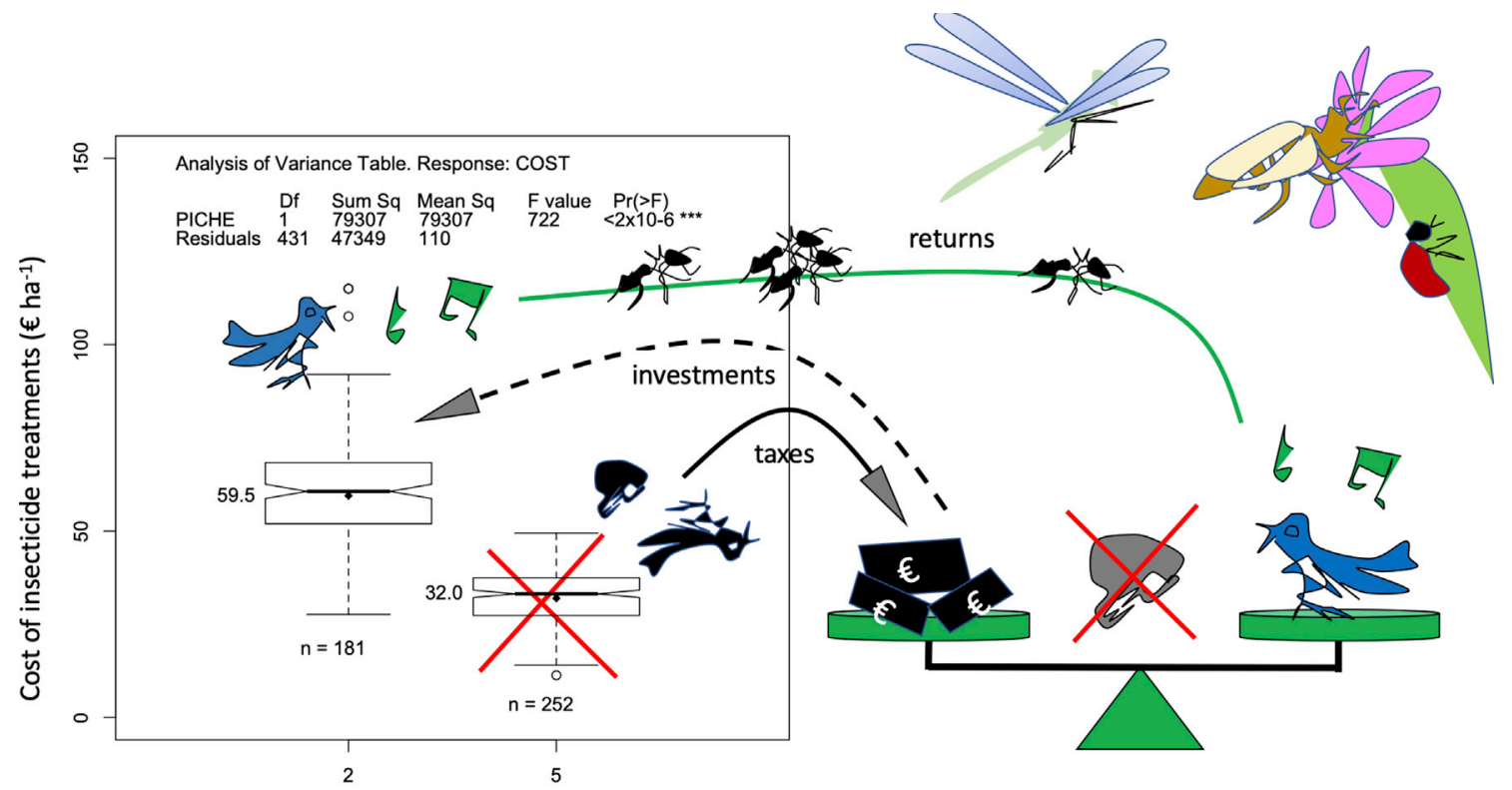

Potential Impact Class on human health (PICHE)

The green balance/way

Fig. 2. Boxplot of dependent variable COST of insecticide treatments against factor PICHE $[(1+2+3)=2$ and 5 levels], with median (thick line in the box), first (down) and third (up) quartiles-sides of the box and $95 \%$ confidence interval of median (whiskers). We added the analysis of variance table, the mean (rhomboid point in the boxes), and the number of investigated treatments in each PICHE. A notch is drawn in each side of the boxes. Similar shapes and ranges indicate equal variance. If the notches of two plots do not overlap this is 'strong evidence' that the two medians differ. Pesticide taxes can be a useful component of an optimal pesticide policy. Growers may even be willing to pay more for products that are effective against problematic pests because they are less harmful to human health and the environment.

\section{Theory/calculation: how much does a healthier agriculture cost?}

The average cost of the insecticides fluctuated from $59.5 € \mathrm{ha}^{-1} \mathrm{yr}^{-1}$ for the less toxic class (PICHE 2) to $32.0 € \mathrm{ha}^{-1} \mathrm{yr}^{-1}$ for the more dangerous ones to human health (PICHE 5) (Fig. 2). Because of this cost difference, farmers tend to use the less expensive insecticides that are more harmful to humans and the environment, as opposed to the more expensive ones that 
cause less overall damage. This negative externality should be balanced by an intervention of public institutions, taxing the more dangerous products.

Assuming that the treatments of different PICHEs are interchangeable and that treatments belonging to enlarged PICHE 2 have the same efficacy as those of PICHE 5, we simulated taxation of the PICHE 5 treatments to promote the use of the less impactful on human health PICHE 2 ingredients (Table 3). The difference between the average cost of treatments belonging to PICHE 2 and PICHE 5 is $27.50 €$. To reduce the use of the more dangerous active ingredients, we propose to increase the price of the PICHE 5 treatments with the taxation of at least the $85.93 \%$ of the current average price (column 4 ). The average cost of a virtual treatment that contains active ingredients PICHE 2 and 5 in the proportion used by farmers during the 2015-2017 period would be equal to $44.65 € \mathrm{ha}^{-1}$ [Table 3 : columns $(2) \mathrm{x}(6)=(7)$ ]. Each winegrower usually carries out three treatments per year, so the annual cost of defense against insects would be equal to $44.65 \times 3=133.95 € \mathrm{ha}^{-1} \mathrm{yr}^{-1}$. In a hypothetical scenario where the farms would use only PICHE 2 active ingredients, the cost of the defense goes up to $59.5 \times 3=178.5 € \mathrm{ha}^{-1} \mathrm{yr}^{-1}$, with an extra cost of $178.5-133.95=44.55 € \mathrm{ha}^{-1}$. Considering the Italian vineyard area of 645,984 ha (ISTAT, 2019), the cost would be equal to $44.55 \times 645,984=28,778,587 € \mathrm{yr}^{-1}$ at the national level. This sum obtainable from taxation equals about $2.5 \%$ of the expected expenditure of the Italian Ministry of Agricultural, Food, Forestry and Tourism Policies for 2019 (Ministero dell'Economia e delle Finanze - Dipartimento della Ragioneria Generale dello Stato, 2019).

\section{Discussion and conclusions}

\subsection{The same active ingredients and insecticides are employed worldwide}

On average, the Venetian companies carry out three treatments per year with 27 active ingredients contained in 69 commercial insecticides, mainly for the control of moths (Lobesia botrana/Eupoecilia ambiguella: 1.31 treatments farm-1 yr-1 with 19 active ingredients), leafhoppers (Empoasca vitis/Scaphoideus titanus/Zygina rhamni: 1.19 tearments farm-1 yr-1 with 22 active ingredients) and Cochineal (Neopulvinaria innumerabilis/Pulvinaria vitis: 0.33 treatments farm-1 yr-1, with 13 active ingredients). Two farms made one treatment during the three years period against other insects. The cheapest treatments (PICHE 5) were the most used (252 treatments against 181) and even the most dangerous (PICHE 5) for human health (Fig. 2).

Growers spend an average of $875.77 €$ ha- 1 yr- 1 on pesticides. In this Italian area, the cost of insecticides is lower compared to the cost of fungicides, since the microclimate of the area favors the development of many fungal pathogens.

Table 2

List of active ingredients used by growers, associated PICHE (Potential Impact Class - Human Health), target insects, sum of treatments (total number of treatments during the period of three years: 2015, 2016 and 2017) and dosages.

\begin{tabular}{|c|c|c|c|c|}
\hline Active ingredient & \multicolumn{2}{|c|}{ PICHE Insect } & \multirow{2}{*}{$\begin{array}{l}\text { Number of } \\
\text { treatments }\end{array}$} & \multirow{2}{*}{$\begin{array}{l}\text { Dosage (kg ha- } \\
\text { 1) } \\
0.013\end{array}$} \\
\hline ABAMECTIN (AKA AVERMECTIN) & 5 & Mites & & \\
\hline ACRINATHRIN & 5 & Mites, Thrips & 11 & 0.022 \\
\hline CHLORPYRIFOS & 5 & Moth Leafhoppers Thrips & 69 & 0.36 \\
\hline CHLORPYRIFOS-METHYL & 5 & $\begin{array}{l}\text { Moth Leafhoppers Thrips } \\
\text { Cochineal }\end{array}$ & 34 & 0.45 \\
\hline CYPERMETHRIN & 5 & Moth & 6 & 0.03 \\
\hline DELTAMETHRIN & 5 & Moth & 11 & 0.017 \\
\hline EMAMECTIN BENZOATE & 5 & Moth & 49 & 0.05 \\
\hline INDOXACARB & 5 & Moth & 39 & 0.055 \\
\hline TAU-FLUVALINATE & 5 & Cochineal & 8 & 0.072 \\
\hline ETOFENPROX & 3 & $\begin{array}{l}\text { Leafhoppers Moth Thrips } \\
\text { Metcalfa }\end{array}$ & 3 & 0.06 \\
\hline AZADIRACHTINA & 3 & Moth Leafhoppers Thrips & 3 & 0.143 \\
\hline SPIROTETRAMAT & 3 & Cochineal & 5 & 0.03 \\
\hline ACETAMIPRID & 2 & Leafhoppers, Aphids & 19 & 0.072 \\
\hline BUPROFEZIN & 2 & Leafhoppers & 16 & 0.375 \\
\hline CHLORANTRANILIPROLE & 2 & Moth & 7 & 0.05 \\
\hline HEXYTHIAZOX & 2 & Mites & 1 & 0.05 \\
\hline METALDEHYDE & 2 & Gastropods & 1 & 0.001 \\
\hline METHOXYFENOZIDE & 2 & Moths & 27 & 0.096 \\
\hline PYRETHRINS & 2 & Aphids & 13 & 0.038 \\
\hline PYRIPROXYFEN & 2 & Cochineal & 1 & 0.008 \\
\hline SPINOSAD & 2 & Moth & 7 & 0.096 \\
\hline TEBUFENOZIDE & 2 & Moth & 2 & 0.172 \\
\hline THIAMETHOXAM & 2 & Leafhoppers Cochineal & 58 & 0.072 \\
\hline ACIBENZOLAR-S-METHYL & 1 & Mites & 1 & 4 \\
\hline AZADIRACHTIN A & 1 & Leafhoppers & 6 & 0.02 \\
\hline BACILLUS THURINGIENSIS SUBSPP & 1 & Leafhoppers, Moths & 5 & 0.127 \\
\hline $\begin{array}{l}\text { FATTY ACIDS C7-C18 AND C18, UNSATURATED POTASSIUM SALTS (CAS } \\
67,701-09-1 \text { ) }\end{array}$ & 1 & Leafhoppers, Mites and Trips & 6 & 3.51 \\
\hline
\end{tabular}


Table 3

Calculation of the cost of a single virtual treatment composed of treatments belonging to PICHE 2 and 5 in the proportions used in the years 2015 , 2016 and 2017 in the vineyards of Veneto Region (Italy).

\begin{tabular}{|c|c|c|c|c|c|c|}
\hline 1 & 2 & 3 & 4 & 5 & 6 & 7 \\
\hline PICHE & $\begin{array}{l}\text { Average cost of } \\
\text { insecticides ( } € \\
\text { treatment }^{-1} \text { ) }\end{array}$ & $\begin{array}{l}\text { Difference cost with } \\
\text { PICHE } 2 \text { insecticides ( } €^{-1} \text { ) } \\
\text { treatment }^{-1} \text { ) }\end{array}$ & $\begin{array}{l}\text { Difference cost } \\
\text { with PICHE } 2 \\
\text { insecticides (\%) }\end{array}$ & $\begin{array}{l}\text { Number of treatments } \\
\text { (during three years: } \\
2015,2016,2017 \text { ) }\end{array}$ & $\begin{array}{l}\text { Number of } \\
\text { treatments }\end{array}$ & $\begin{array}{l}\text { Average cost of a virtual treatment made of } \\
\text { mixed PICHEs } 2 \text { and } 5 \text { treatments. Column } \\
\text { n. } 2 \text { x column n. } 6\end{array}$ \\
\hline 2 & 59.5 & 0 & 0 & 181 & 46 & 27.37 \\
\hline 5 & 32 & 27.5 & 85.93 & 252 & 54 & 17,28 \\
\hline Total & & & & 433 & 100 & 44.65 \\
\hline
\end{tabular}

Insecticides amount to $133.95 €$ ha- $1 \mathrm{yr}-1$ (15.3\%), with considerable variability from grower to grower (from 22 to $425 €$ ha- 1 $\mathrm{yr}-1$ ), based on weather conditions and the types of practices (organic, integrated or conventional agriculture).

The list of active ingredients of insecticides used in Italy (Table 2) complies with the ranges allowed in Europe (Commissariat Géneral au Développement Durable, 2015; Excell Laboratoire, 2014; Food European Authority Safety, 2018; Herrero-Hernández et al., 2017, 2013; Lewis et al., 2016; Miyake et al., 2012; Wuttke et al., 1999) and the United States (California Department of Pesticide Regulation, 2011; Stone et al., 2014; USDA Agricultural Marketing Service, 2017). Multinational companies sell insecticides with the same active ingredients all over the world. The same mechanism adopted in Vento likely acts also at a global scale: lower priced but harmful insecticides make farmers inclined to use them, without an awareness of the severe consequences on the environment and human health.

\subsection{Relationship between insecticides and environment}

A supplemental analysis of Environmental PICs and cost revealed a negative correlation between PIC and cost (article in preparation). The correlation coefficient between Health and Environmental PICs was $0.719(\mathrm{p}<0.01)$, demonstrating a relationship between the two variables. This means that insecticides that cost less are those that more negatively effect on both humans and the environment. The water PIC instead was different (Health and Water PICs: $r=0.33 ; \mathrm{p}<0.01$ ), and there was no correlation with the cost of the insecticides. The reason is that low water PIC values were assigned to active ingredients which are removed quickly from the application area through water flow (Franchi and Arpat Direzione Tecnica, 2017). This means that they may impact the area where they are applied only for a short time, but their potential hazard may be carried elsewhere. The large variability of the price of insecticides with the same active ingredients were many and mainly linked to localized availability of the product, quality of the company, advertising, experience, habits and methods of distribution of the user, but also to biological and climatic variables and to the repercussions of the global market.

The biodiversity of the planet is in danger (Ripple et al., 2018). Many habitats have lost a huge amount of species of insects, followed by birds and mammals further along the food chain (English et al., 2018; Main et al., 2018; Ponge, 2005; Regan et al., 2015; Sanchez et al., 2003; Stanton et al., 2018; Vašíčková et al., 2019). Climate changes, decreases in soil quality/fertility and increase in soil consumption (Böcker and Finger, 2016; Caitlin et al., 2017; Silva et al., 2019; Zanella and Ascher-Jenull, 2018) and a loss of biodiversity (Blakemore, 2018; Dairon et al., 2017; Fusaro, 2015; Gross, 2015; Hallmann et al., 2014, 2017; Hanspach et al., 2017; Hillocks, 2012; Horowitz and Lichtenberg, 1994; Inger et al., 2015; Kudsk et al., 2018; Magkos et al., 2006; Regan et al., 2015; Schipanski et al., 2014) are occurring in our planet. At the same time, we need to control invasive arthropod species (Daane et al., 2018). In 2050 ( 9 billion people), the use of pesticides is estimated to be 2.7 times higher than that of 2000. Every year, almost 12.6 million people die from diseases associated with environmental hazards, such as air, water and/or soil pollution, and climate change (FAO, 2019; Sexton, 2007). Global cost/benefit of pesticide use (total) has increased with time from 1990 to 2007 and has been declining since 2007 (Zhang, 2018). The social communities involved in the food and agricultural sectors need to find innovative ways to increase fruit and vegetable production to meet population health needs (Siegel et al., 2014). Chemical mixtures of pesticides can dangerously promote antibiotic resistance (Ye et al., 2017), but biological control could partially replace the use of chemicals in agriculture. As consumers, we generally accept spending more for issues related to health. Farmers may be willing to pay more for products that are effective against problematic pests because they are less harmful to their health and the environment, but too often growers are informed only about the efficacy of the pesticide and not on their consequences on human health and the environment.

Alone or associated with the applied volume of insecticides, PIC index (and notably the Potential Impact Class on human health, PICHE) can be a guide to making better choices toward environmental sustainability. It can be used to support the planning phase for protecting both regional (rural development plans) and sectoral (water management plans, regulation of protected ecosystems) areas, and it can also be adopted as a tool for monitoring and evaluating the outcome of sustainable strategies in the agricultural sector, as in the case of Sustainable Intensification indicator (Mahon et al., 2018).

Pesticide taxes can be a useful component of an optimal pesticide policy (Skevas et al., 2012). Taxation related to pesticide toxicity is under discussion in Europe (SCHEER, 2018). Unlike other instruments, taxation may influence farmers' flexibility in their choices and does not require the introduction of regulating enforcement procedures or farm sanctions. 


\section{Funding}

This research did not receive any specific grant from funding agencies in the public, commercial, or not-for-profit sectors.

\section{References}

Ansari, M.S., Moraiet, M.A., Ahmad, S., 2014. Insecticides: impact on the environment and human health. In: Environmental Deterioration and Human Health. Springer Netherlands, Dordrecht, pp. 99-123. https://doi.org/10.1007/978-94-007-7890-0_6.

Barca, B., Lindon, A., Root-Bernstein, M., 2016. Environmentalism in the crosshairs: perspectives on migratory bird hunting and poaching conflicts in Italy. Glob. Ecol. Conserv. 6, 189-207. https://doi.org/10.1016/j.gecco.2016.03.001.

Benelli, G., 2018. Gold nanoparticles - against parasites and insect vectors. Acta Trop. 178, 73-80. https://doi.org/10.1016/J.ACTATROPICA.2017.10.021.

Bertrand, M., Barot, S., Blouin, M., Whalen, J., de Oliveira, T., Roger-Estrade, J., 2015. Earthworm services for cropping systems. A review. Agron. Sustain. Dev. 35, 553-567. https://doi.org/10.1007/s13593-014-0269-7.

Bianco, P.A., Alma, A., Casati, P., Scattini, G., Arzone, A., 2001. Transmission of 16SrV phytoplasmas by Scaphoideus titanus ball in northern Italy. Plant Protect. Sci. 37, 49-56. https://doi.org/10.17221/8365-PPS.

Blakemore, R., 2018. Critical decline of earthworms from organic origins under intensive, humic SOM-depleting agriculture. Soil Syst 2, 33. https://doi.org/ $10.3390 /$ soilsystems2020033.

Böcker, T., Finger, R., 2016. European pesticide tax schemes in comparison: an analysis of experiences and developments. Sustainability 8, 378. https://doi. org/10.3390/su8040378.

Caitlin, E., Hicks, P., Castanha, C., Porras, R.C., Torn, M.S., 2017. The whole-soil carbon flux in response to warming. Science (80-. ) 355, 1420-1423. https:// doi.org/10.1126/science.aal1319.

California Department of Pesticide Regulation, 2011. Summary of pesticide use report data 2010 indexed by commodity. In: Chapter 4. Trends in Use in Certain Pesticide Categories. Tables 4 to 19.

Commissariat Géneral au Développement Durable, 2015. Les pesticides dans les cours d'eau francais en 2013.

Daane, K.M., Vincent, C., Isaacs, R., Ioriatti, C., 2018. Entomological opportunities and challenges for sustainable viticulture in a global market. Annu. Rev. Entomol. 63, 193-214. https://doi.org/10.1146/annurev-ento-010715-023547.

Dairon, R., Dutertre, A., Tournebize, J., Marks-Perreau, J., Carluer, N., 2017. Long-term impact of reduced tillage on water and pesticide flow in a drained context. Environ. Sci. Pollut. Res. 24, 6866-6877. https://doi.org/10.1007/s11356-016-8123-x.

Datta, S., Singh, Joginder, Singh, S., Singh, Jaswinder, 2016. Earthworms, pesticides and sustainable agriculture: a review. Environ. Sci. Pollut. Res. 23, 8227-8243. https://doi.org/10.1007/s11356-016-6375-0.

De Gerónimo, E., Aparicio, V.C., Costa, J.L., 2018. Glyphosate sorption to soils of Argentina. Estimation of affinity coefficient by pedotransfer function. Geoderma 322, 140-148. https://doi.org/10.1016/J.GEODERMA.2018.02.037.

English, P.A., Green, D.J., Nocera, J.J., 2018. Stable isotopes from museum specimens may provide evidence of long-term change in the trophic ecology of a migratory aerial insectivore. Front. Ecol. Evol. 6. Independent, nonprofit journalism for a livable pl. https://doi.org/10.3389/fevo.2018.00014.

Excell Laboratoire, 2014. Excell Phytocheck - Au delà des exigences de la réglementation. Fungicides, insecticides, herbicides [WWW Document]. Lab. Excell - Bull. Tech. http://www.labexcell.com/wp-content/uploads/2015/01/Excell-Phytocheck-rev-1.pdf (accessed 7.9.19).

FAO, 2019. FAOSTAT/Data/Pesticides/Visualize Data. Country/Region: World. Pesticide - Use Per Area of Cropland (Kg/ha). Average 1990-2016. Map. [WWW Document]. FAOSTAT. URL. http://www.fao.org/faostat/en/\#data/EP/visualize.

Fermaud, M.,L.M.R., 1992. Transmission of Botrytis cinerea to grape by grape berry moth larvae. Phytopathology 82.

Food European Authority Safety, 2018. The 2016 European Union report on pesticide residues in food. EFSA J 16, 1-139. https://doi.org/10.2903/j.efsa.2018. 5348.

Franchi, A., Arpat Direzione Tecnica, 2017. Pesticides Class of Potential Impact - CIP an Indicator to Drive Sustainable Choices. Firenze, Italy.

Fusaro, S., 2015. Evaluation, maintenance and improvement of biodiversity for environmental protection and crop. In: Squartini, A., Paoletti, G.M. (Eds.), Doctorate Thesis. Università degli Studi di Padova (Italia), p. 255.

Gilden, R.C., Huffling, K., Sattler, B., 2010. Pesticides and health risks. J. Obstet. Gynecol. Neonatal Nurs. 39, 103-110. https://doi.org/10.1111/j.1552-6909. 2009.01092.x.

Gross, M., 2015. Europe's bird populations in decline. Curr. Biol. 25, R483-R485. https://doi.org/10.1016/j.cub.2015.05.057.

Hallmann, C.A., Foppen, R.P.B., van Turnhout, C.A.M., de Kroon, H., Jongejans, E., 2014. Declines in insectivorous birds are associated with high neonicotinoid concentrations. Nature 511, 341.

Hallmann, C.A., Sorg, M., Jongejans, E., Siepel, H., Hofland, N., Schwan, H., Stenmans, W., Müller, A., Sumser, H., Hörren, T., Goulson, D., de Kroon, H., 2017. More than 75 percent decline over 27 years in total flying insect biomass in protected areas. PLoS One 12, e0185809. https://doi.org/10.1371/journal. pone.0185809.

Hanspach, J., Abson, D.J., French Collier, N., Dorresteijn, I., Schultner, J., Fischer, J., 2017. From trade-offs to synergies in food security and biodiversity conservation. Front. Ecol. Environ. 15, 489-494. https://doi.org/10.1002/fee.1632.

Hart, K., Pimentel, D., 2002. Public health and costs of pesticides. In: Encyclopedia of Pest Management. CRC Press, pp. 677-679. https://doi.org/10.1023/A: 1021966705566.

Herrero-Hernández, E., Andrades, M.S., Álvarez-Martín, A., Pose-Juan, E., Rodríguez-Cruz, M.S., Sánchez-Martín, M.J., 2013. Occurrence of pesticides and some of their degradation products in waters in a Spanish wine region. J. Hydrol. 486, 234-245. https://doi.org/10.1016/j.jhydrol.2013.01.025.

Herrero-Hernández, E., Rodríguez-Cruz, M.S., Pose-Juan, E., Sánchez-González, S., Andrades, M.S., Sánchez-Martín, M.J., 2017. Seasonal distribution of herbicide and insecticide residues in the water resources of the vineyard region of La Rioja (Spain). Sci. Total Environ. 609, 161-171. https://doi.org/10. 1016/j.scitotenv.2017.07.113.

Hillocks, R.J., 2012. Farming with fewer pesticides: EU pesticide review and resulting challenges for UK agriculture. Crop Protect. 31, 85-93. https://doi.org/ 10.1016/j.cropro.2011.08.008.

Horowitz, J.K., Lichtenberg, E., 1994. Risk-reducing and risk-increasing effects of pesticides. J. Agric. Econ. 45, 82-89. https://doi.org/10.1111/j.1477-9552. 1994.tb00379.x.

Horrigan, L., Lawrence, R.S., Walker, P., 2002. How sustainable agriculture can address the environmental and human health harms of industrial agriculture. Environ. Health Perspect. 110, 445-456. https://doi.org/10.1289/ehp.02110445.

Inger, R., Gregory, R., Duffy, J.P., Stott, I., Vořǐšek, P., Gaston, K.J., 2015. Common European birds are declining rapidly while less abundant species' numbers are rising. Ecol. Lett 18, 28-36. https://doi.org/10.1111/ele.12387.

ISTAT, 2019. Agriculture - Crops and livestock-Crops-Grapes, wine, olives, oil: wine grapes [WWW Document]. I.Stat. Your direct access to Ital. Stat. http:// dati.istat.it/Index.aspx?Queryld=33654.

Khalil, M.I., Osborne, B.A., 2018. Improving estimates of soil organic carbon (SOC) stocks and their long-term temporal changes in agricultural soils in Ireland. Geoderma 322, 172-183. https://doi.org/10.1016/j.geoderma.2018.02.038.

Kudsk, P., Jørgensen, L.N., Ørum, J.E., 2018. Pesticide Load-a new Danish pesticide risk indicator with multiple applications. Land Use Policy 70, $384-393$. https://doi.org/10.1016/j.landusepol.2017.11.010.

Lehikoinen, A., Brotons, L., Calladine, J., Campedelli, T., Escandell, V., Flousek, J., Grueneberg, C., Haas, F., Harris, S., Herrando, S., Husby, M., Jiguet, F., Kålås, J.A. , Lindström, Å., Lorrillière, R., Molina, B., Pladevall, C., Calvi, G., Sattler, T., Schmid, H., Sirkiä, P.M., Teufelbauer, N., Trautmann, S., 2018. Declining population trends of European mountain birds. Glob. Chang. Biol. gcb. 14522. https://doi.org/10.1111/gcb.14522. 
Lewis, K.A., Tzilivakis, J., Warner, D.J., Green, A., 2016. An international database for pesticide risk assessments and management. Hum. Ecol. Risk Assess. Int. J. 22, 1050-1064. https://doi.org/10.1080/10807039.2015.1133242.

Lidskog, R., Elander, I., 2012. Ecological modernization in practice? The case of sustainable development in Sweden. J. Environ. Policy Plan. 14, 411-427. https://doi.org/10.1080/1523908X.2012.737234.

Lucchi, A., 2014. Note di Entomologia Viticola. Pisa University Press.

Magkos, F., Arvaniti, F., Zampelas, A., 2006. Organic food: buying more safety or just peace of mind? A critical review of the literature. Crit. Rev. Food Sci. Nutr. 46, 23-56. https://doi.org/10.1080/10408690490911846.

Mahon, N., Crute, I., Di Bonito, M., Simmons, E.A., Islam, M.M., 2018. Towards a broad-based and holistic framework of Sustainable Intensification indicators. Land Use Policy 77, 576-597. https://doi.org/10.1016/j.landusepol.2018.06.009.

Main, A.R., Webb, E.B., Goyne, K.W., Mengel, D., 2018. Neonicotinoid insecticides negatively affect performance measures of non-target terrestrial arthropods: a meta-analysis. Ecol. Appl. 28, 1232-1244. https://doi.org/10.1002/eap.1723.

Marín-Benito, J.M., Herrero-Hernández, E., Rodríguez-Cruz, M.S., Arienzo, M., Sánchez-Martín, M.J., 2017. Study of processes influencing bioavailability of pesticides in wood-soil systems: effect of different factors. Ecotoxicol. Environ. Saf. 139, 454-462. https://doi.org/10.1016/j.ecoenv.2017.02.012.

Mascarelli, A., 2013. Children's environ- mental health. Science 84 341, 740-741. https://doi.org/10.1126/science.341.6147.740.

Matyjaszczyk, E., Karmilowicz, E., Skrzecz, I., 2019. How European Union accession and implementation of obligatory integrated pest management influenced forest protection against harmful insects: a case study from Poland. For. Ecol. Manage. 433, 146-152. https://doi.org/10.1016/j.foreco.2018.11. 001.

Meersmans, J., van Wesemael, B., De Ridder, F., Van Molle, M., 2009. Modelling the three-dimensional spatial distribution of soil organic carbon (SOC) at the regional scale (Flanders, Belgium). Geoderma 152, 43-52. https://doi.org/10.1016/j.geoderma.2009.05.015.

Ministero dell'Economia e delle Finanze - Dipartimento della Ragioneria Generale dello Stato, 2019. Nota integrativa a legge di bilancio per l'anno 2019 e per il triennio 2019-2021 (art. 21 della Legge n. 196/2009.

Miyake, S., Renouf, M., Peterson, A., McAlpine, C., Smith, C., 2012. Land-use and environmental pressures resulting from current and future bioenergy crop expansion: a review. J. Rural Stud. 28. https://doi.org/10.1016/j.jrurstud.2012.09.002.

Moeder, M., Bauer, C., Popp, P., van Pinxteren, M., Reemtsma, T., 2012. Determination of pesticide residues in wine by membrane-assisted solvent extraction and high-performance liquid chromatography-tandem mass spectrometry. Anal. Bioanal. Chem. 403, 1731-1741. https://doi.org/10.1007/s00216-0125956-0.

Nicolopoulou-Stamati, P., Maipas, S., Kotampasi, C., Stamatis, P., Hens, L., 2016. Chemical pesticides and human health: the urgent need for a new concept in agriculture. Front. Public Heal 4. https://doi.org/10.3389/fpubh.2016.00148.

Pelosi, C., Pey, B., Hedde, M., Caro, G., Capowiez, Y., Guernion, M., Peigné, J., Piron, D., Bertrand, M., Cluzeau, D., 2014. Reducing tillage in cultivated fields increases earthworm functional diversity. Appl. Soil Ecol. 83, 79-87. https://doi.org/10.1016/j.apsoil.2013.10.005.

Pergola, M., Persiani, A., Palese, A.M., Meo, V. Di, Pastore, V., D'Adamo, C., Celano, G., 2018. Composting: the way for a sustainable agriculture. Appl. Soil Ecol. 123. https://doi.org/10.1016/j.apsoil.2017.10.016.

Pimentel, D., 2005. Environmental and economic costs of the application of pesticides primarily in the United States. Environ. Dev. Sustain. 7, 229-252. https://doi.org/10.1007/s10668-005-7314-2.

Ponge, J.-F., 2005. Emergent properties from organisms to ecosystems: towards a realistic approach. Biol. Rev. 80, 403-411. https://doi.org/10.1017/ s146479310500672x.

Prashar, P., Shah, S., 2016. Impact of fertilizers and pesticides on soil microflora in agriculture. In: Lichtfouse, E. (Ed.), Sustainable Agriculture Reviews:, vol 19. Springer International Publishing, Cham, pp. 331-361. https://doi.org/10.1007/978-3-319-26777-7 8.

Prashar, P., Shah, S., 2013. Sustainable Agriculture Reviews, Sustainable Agriculture Reviews, Sustainable Agriculture Reviews. Springer Netherlands, Dordrecht. https://doi.org/10.1007/978-94-007-5961-9.

Regan, E.C., Santini, L., Ingwall-King, L., Hoffmann, M., Rondinini, C., Symes, A., Taylor, J., Butchart, S.H.M., 2015. Global trends in the status of bird and mammal pollinators. Conserv. Lett. 8, 397-403. https://doi.org/10.1111/conl.12162.

Remlein-Starosta, D., Drożdżyński, D., Kowalska, J., 2015. Occurrence of fungal and pesticides contamination in rapeseeds depending on the cultivars and systems of farming. Plant Soil Environ. 61, 49-54. https://doi.org/10.17221/760/2014-PSE.

Ripple, W.J., Wolf, C., Galetti, M., Newsome, T.M., Green, T.L., Alamgir, M., Crist, E., Mahmoud, M.I., Laurance, W.F., 2018. The role of scientists' warning in shifting policy from growth to conservation economy. Bioscience 68, 239-240. https://doi.org/10.1093/biosci/biy009.

Sanchez, P.A., Palm, C.A., Buol, S.W., 2003. Fertility capability soil classification: a tool to help assess soil quality in the tropics. Geoderma $114,157-185$. https://doi.org/10.1016/S0016-7061(03)00040-5.

Sarwar, M., 2015. The killer chemicals as controller of agriculture insect pests: the conventional insecticides. Int. J. Chem. Biomol. Sci. 1, 141-147.

SCHEER, 2018. Statement on emerging health and environmental issues. In: European Commission DG Health and Food Safety Directorate C: Public Health, Country Knowledge, Crisis Management Unit C2 - Country Knowledge and Scientific Committees. https://doi.org/10.2875/840266.

Schipanski, M.E., Barbercheck, M., Douglas, M.R., Finney, D.M., Haider, K., Kaye, J.P., Kemanian, A.R., Mortensen, D.A., Ryan, M.R., Tooker, J., White, C., 2014. A framework for evaluating ecosystem services provided by cover crops in agroecosystems. Agric. Syst. 125. https://doi.org/10.1016/j.agsy.2013.11.004.

Sexton, S.E., 2007. The economics of pesticides and pest control. Int. Rev. Environ. Resour. Econ. 1, 271-326. https://doi.org/10.1561/101.00000007.

Siegel, K.R., Ali, M.K., Srinivasiah, A., Nugent, R.A., Narayan, K.M.V., 2014. Do we produce enough fruits and vegetables to meet global health need? PLoS One 9, e104059. https://doi.org/10.1371/journal.pone.0104059.

Silva, V., Mol, H.G.J., Zomer, P., Tienstra, M., Ritsema, C.J., Geissen, V., 2019. Pesticide residues in European agricultural soils - a hidden reality unfolded. Sci. Total Environ. 653, 1532-1545. https://doi.org/10.1016/j.scitotenv.2018.10.441.

Skevas, T., Stefanou, S.E., Lansink, A.O., 2012. Can economic incentives encourage actual reductions in pesticide use and environmental spillovers? Agric. Econ. 43, 267-276. https://doi.org/10.1111/j.1574-0862.2012.00581.x.

Spina, F., Cecchi, G., Landinez-Torres, A., Pecoraro, L., Russo, F., Wu, B., Cai, L., Liu, X.Z., Tosi, S., Varese, G.C., Zotti, M., Persiani, A.M., 2018. Fungi as a toolbox for sustainable bioremediation of pesticides in soil and water. Plant Biosyst. 152, 474-488. https://doi.org/10.1080/11263504.2018.1445130.

Stanton, R.L., Morrissey, C.A., Clark, R.G., 2018. Analysis of trends and agricultural drivers of farmland bird declines in North America: a review. Agric. Ecosyst. Environ. 254, 244-254. https://doi.org/10.1016/j.agee.2017.11.028.

Stone, Wesley W., Gilliom, Robert J., Martin, J.D., 2014. An Overview Comparing Results from Two Decades of Monitoring for Pesticides in the Nation's Streams and Rivers, 1992-2001 and 2002-2011. Natl. Water-Quality Assess, pp. 1-23. https://doi.org/10.3133/sir20145154.

Travisi, C., Nijkamp, P., Vighi, M., Giacomelli, P., 2004. Managing Pesticide Risks for Non-target Ecosystems with Pesticide Risk Indicators. Ssrn. https://doi. org/10.2139/ssrn.558625.

USDA Agricultural Marketing Service, 2017. The National List of Allowed and Prohibited Substances, Code of Federal Regulations.

Vašíčková, J., Hvězdová, M., Kosubová, P., Hofman, J., 2019. Ecological risk assessment of pesticide residues in arable soils of the Czech Republic. Chemosphere 216, 479-487. https://doi.org/10.1016/j.chemosphere.2018.10.158.

Vernier, F., Leccia-Phelpin, O., Lescot, J.-M., Minette, S., Miralles, A., Barberis, D., Scordia, C., Kuentz-Simonet, V., Tonneau, J.-P., 2017. Integrated modeling of agricultural scenarios (IMAS) to support pesticide action plans: the case of the Coulonge drinking water catchment area (SW France). Environ. Sci. Pollut. Res. 24, 6923-6950. https://doi.org/10.1007/s11356-016-7657-2.

Wuttke, W., Jarry, H., Seidlová, D., 1999. Endocrine Disrupters, Reproduktionsmedizin. https://doi.org/10.1007/s004440050072.

Ye, J., Rensing, C., Su, J., Zhu, Y.-G., 2017. From chemical mixtures to antibiotic resistance. J. Environ. Sci. 62, 138-144. https://doi.org/10.1016/j.jes.2017.09. 003.

Zanella, A., Ascher-Jenull, J., 2018. Editorial. Appl. Soil Ecol. 122, 1-9. https://doi.org/10.1016/j.apsoil.2017.11.029. 
Zanella, A., Bolzonella, C., Lowenfels, J., Ponge, J.-F., Bouché, M., Saha, D., Kukal, S.S., Fritz, I., Savory, A., Blouin, M., Sartori, L., Tatti, D., Kellermann, L.A., Trachsel, P., Burgos, S., Minasny, B., Fukuoka, M., 2018. Humusica 2, article 19: techno humus systems and global change-conservation agriculture and 4/1000 proposal. Appl. Soil Ecol. 122, 271-296. https://doi.org/10.1016/j.apsoil.2017.10.036.

Zhang, W., 2018. Global pesticide use: profile, trend, cost/benefit and more. Proc. Int. Acad. Ecol. Environ. Sci. 8, 1-27.

Zilberman, D., Millock, K., 1997. Financial incentives and pesticide use. Food Policy 22, 133-144. https://doi.org/10.1016/S0306-9192(97)00004-3. 